\title{
Chylopericardium in a child with $\lg A$ nephropathy: a case report
}

\author{
Yu-lin Kang ${ }^{1}$, Yun Cui ${ }^{2}$, Ying Wu', Shen Hao ${ }^{1}$, Xin-yu Kuang ${ }^{1}$, Yu-cai Zhang ${ }^{2}$, Wen-yan Huang ${ }^{1}$ \\ and Guang-hua Zhu*
}

\begin{abstract}
Background: Chylopericardium effusion is characterized by the accumulation of milky effusion in the pericardium. It is often idiopathic but it can be secondary to trauma, chest radiation, tuberculosis and malignancy. If cardiac tamponade ensues, it becomes life-threatening. Herein we describe chylopericardium tamponade in a child with IgA nephropathy. To the best of our knowledge, this is the first reported case of chylopericardium tamponade in IgA nephropathy.
\end{abstract}

Case presentation: A 6 years old boy with IgA nephropathy presented with dyspnea, orthopnea, pretibial pitting edema, ascites and fever. Muffled heart sounds and hepatomegaly were also noted. Echocardiography and thoracic CT revealed that there was a large volume of hydropericardium. Moreover, the pericardial milky fluid by pericardiocentesis was analyzed and chylopericardium effusion was eventually confirmed. Pericardial drainage was continued and his diet was modified to low fat, rich MCT and high protein. Complete remission was achieved after 3 weeks of this combined treatment.

Conclusion: Chylopericardial tamponade could be a rare and life-threatening complication of IgA nephropathy. Etiological analysis is critical for determining the therapeutic approach in patients with pericardial effusion.

Keywords: Chylopericardium tamponade, IgA nephropathy, Pericardiocentesis, Pericardium drainage, Middle chain triglyceride

\section{Background}

Pericardial effusion is a rare complication in renal diseases and could lead to hemodynamic compromise. Patients may initially present with clinical tamponade, characterized by dyspnea, tachycardia, jugular venous distension or even shock, while others may be asymptomatic if pericardial fluid accumulation is small $[1,2]$. Pericardial effusion may be idiopathic or secondary to underlying diseases, such as acute myocardial infarction, end stage renal disease and autoimmune diseases [3-5]. Prompt diagnosis is critical. However, chylopericardial effusions may be difficult to diagnose unless the pericardial fluid undergoes chemical analysis. It is recognized that chylopericardium effusion may result from trauma, infection or blockage of the lymphatics [6]. In this paper, to the best of our knowledge, we are presenting the first

\footnotetext{
* Correspondence: ghzhu301@sjtu.edu.cn

'Department of Nephrology and Rheumatology, Shanghai Children's

Hospital, Shanghai Jiao Tong University, Shanghai, China

Full list of author information is available at the end of the article
}

case of chylopericardial tamponade in a child with IgA nephropathy.

\section{Case presentation}

A 6 years old boy with dyspnea, orthopnea, generalized pitting edema and fever, was admitted to the pediatric intensive care unit, Shanghai Children's Hospital. Three years before this episode, he presented to our hospital with acute onset of edema, hypoalbuminemia, heavy proteinuria and hyperlipidemia. The diagnosis of IgA nephropathy (Grade II) was made by percutaneous renal biopsy and in accordance with Lee's classification [7]. Initially he responded well to steroid therapy, but became steroid resistant after 2 years treatment. Immunosuppressive agents administered during this time period, included cyclophosphamide, mycophenolate mofetil and tacrolimus. He had no history of trauma, tuberculosis or radiation therapy.

Physical examination revealed tachypnea, orthopnea, anasarca and ascites. The heart sounds were muffled 
and hepatomegaly was also noted. Blood pressure ranged from $90 / 60 \mathrm{mmHg}$ (systolic/diastolic blood pressure) to 130/70 mmHg. Blood cell count showed that white blood cells (WBC) was $14.49 \times 10^{9} / \mathrm{L}$, neutrophils $79 \%$, hemoglobin $11.5 \mathrm{~g} / \mathrm{dl}$, C-reactive protein $130 \mathrm{mg} / \mathrm{L}$. Biochemistry analysis revealed total protein of $36 \mathrm{~g} / \mathrm{L}$, albumin $10 \mathrm{~g} / \mathrm{L}$, alanine aminotransferase (ALT) $10 \mathrm{U} /$ $\mathrm{L}$, aspartate aminotransferase (AST) $29 \mathrm{U} / \mathrm{L}$, triglycerides $2.05 \mathrm{mmol} / \mathrm{L}$, cholesterol $10.13 \mathrm{mmol} / \mathrm{L}$. Serum electrolytes $\left(\mathrm{Na}^{+}, \mathrm{K}^{+}, \mathrm{Ca}^{2+}\right.$ and $\left.\mathrm{Cl}^{-}\right)$were normal. Heavy proteinuria and hematuria were found on urinalysis (urinary protein: creatinine ratio 30.38 ). Serum creatinine was normal and estimated glomerular filtration rate (eGFR, calculated with Schwartz formula) was $147 \mathrm{ml} /$ $\mathrm{min} / 1.73 \mathrm{~m}^{2}$. Blood and urine cultures were sterile. T-spot for tuberculosis was negative. There was no ultrasound evidence of thrombosis in the superior vena cava or subclavian vein. Ultrasound also demonstrated that both kidneys were enlarged with a loss of cortico-medullary differentiation. Thoracic computed tomography (CT) found no evidence of congenital malformation or malignancies. Echocardiography revealed pericardial fluid of $4.6 \mathrm{~cm}$ at maximal thickness, suggesting a large volume hydropericardial effusion. The massive pericardial and pleural effusions were additionally confirmed by thoracic CT (Fig. 1a). Notably, milky fluid was obtained from the pericardial space by pericardiocentesis (Fig. 1b). Chyle test was positive. Cell counts and biochemistry in the pericardial effusion revealed WBC $405 \times 10^{6} / \mathrm{L}$, lymphocytes count $92 \%$, red blood cells $63 \times 10^{6} / \mathrm{L}$, AST $8 \mathrm{U} / \mathrm{L}$, lactate dehydrogenase (LDH) $58 \mathrm{U} / \mathrm{L}$, Glucose $7.22 \mathrm{mmol} / \mathrm{L}$, total protein $7 \mathrm{~g} / \mathrm{L}$, albumin $4 \mathrm{~g} / \mathrm{L}$, adenylate deaminase (ADH) $2.6 \mathrm{U} / \mathrm{L}$, triglycerides $2.55 \mathrm{mmol} / \mathrm{L}$, cholesterol $0.79 \mathrm{mmol} / \mathrm{L}$. These findings confirmed the diagnosis of chylopericardial effusion.

Continuous renal replacement (CRRT) therapy was performed to alleviate the fluid overload. Meanwhile, pericardial drainage was performed and the diet was modified to low fat but rich in middle chain triglycerides and high protein. No side effects were encountered with this diet modification. The symptoms of cardiac tamponade subsided promptly, while the edema receded gradually over the subsequent 2 weeks. The indwelling pericardial catheter was removed when no fluid was drained after 3 weeks treatment and as shown in Fig. 1c, the chylopericardial effusion was removed successfully. Pericardial effusion has not recurred at 1 year of follow up, on follow up echocardiography.

\section{Discussion and conclusions}

Chylopericardium is characterized by a milky pericardial effusion, which is saturated with chyle and triglyceride. Clinical manifestations vary from asymptomatic to life threatening pericardial tamponade, depending on the extent of the effusion [8]. Our case highlights the importance of early diagnosis and treatment, as such patients can be easily misdiagnosed. Thoracic and pericardium effusion are seldom suspected to be chylous fluid in nephrotic syndrome unless the fluid sample is specifically analyzed for chyle and triglycerides. Thus, the awareness of chylopericardial tamponade needs to be heightened in renal or rheumatology diseases.

Chylopericardium can be idiopathic or secondary to trauma, tuberculosis, radiation, mediastinal tumor, venous thrombosis and congenital anomalies of the lymphatic duct [9]. Therefore, a history of blunt injury or thoracic operation needs to be reviewed. Neoplasm, thrombosis and congenital malformations should be looked for using CT scan, magnetic resonance imaging (MRI) or ultrasound. Tuberculosis can be excluded by the T-spot assay. Furthermore, lymphangiography and lymphoscintigraphy may be employed to exclude anatomic abnormities of thoracic lymphatic system $[10,11]$. Additionally, it should be recognized that thrombosis and tuberculosis are two common complications seen in nephrotic syndrome and other glomerular diseases with nephrotic range proteinuria. As a
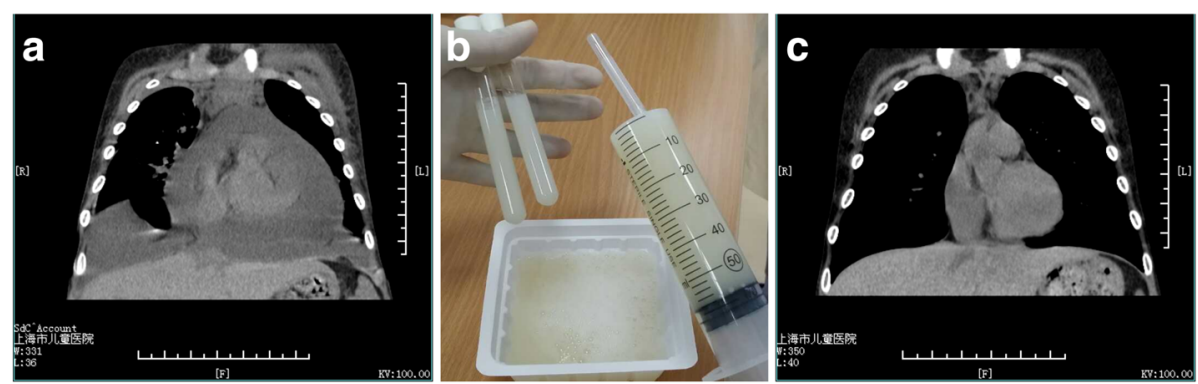

Fig. 1 a Thoracic CT demonstrating massive pericardial and pleural effusion. $\mathbf{b}$ The milky pericardial effusion was obtained from the child with IgA nephropathy. Laboratory tests revealed that this milky pericardial fluid was saturated chylous effusion. c The thoracic CT demonstrating resolution of pericardial effusion after pericardial drainage and modified diet therapy 
result, chylopericardial effusion may occur if the integrity of the lymphatic duct was damaged by such conditions. However, no evidence of any of these causes was present in our case. The diagnosis of idiopathic chylopericardium may be made if no underlying cause is found. It has been reported that idiopathic chylopericardial effusion affects both genders equally and exists in different age groups $[12,13]$. The etiology remains unclear, but it may due to elevated intrathoracic lymphatic pressure, increased permeability of lymphatic vessel walls, or valvular incompetence and ruptured lymphatic valves [6]. The most common manifestations of patients with idiopathic chylopericardial infusion range from absence of symptoms to cough, dyspnea and fatigue. Table 1 details clinical presentations of cases reported in the literature. Our case presented with life threatening dyspnea and orthopnea. Thus, chylopericardial effusion should be suspected, if patients with IgA nephropathy have hydropericardium, given the potential for life threatening complications despite its rarity.

Regarding therapeutic approaches, the most important step is to relieve the symptoms by urgent pericardiocentesis or pericardial drainage, if a life-threatening situation exists [14]. Drainage should not be terminated until the effusion recedes to a very small amount, as it may be helpful for self-repair of the damaged lymphatic tubule. In our case, it took 3 weeks for pericardial drainage to cease suggesting a relatively long duration for self-recovery. Meanwhile, some studies reported other surgical procedures such as ligature and excision of thoracic duct combined with partial pericardiectomy were necessary if pericardial effusion is recurrent [15]. Table 1 summarizes our review of the literature and details different treatments and outcomes. It also has been reported that administration of octreotide is effective in reducing intestinal absorption of fats [13].Most importantly it is necessary to remove any underlying causes for chylopericardial effusion. For instance, if thrombosis is the primary cause of chylopericardial effusion, thrombolytic therapy must be considered. In addition, conservative therapies are also required, including low fat diet based on middle chain triglycerides (MCT) or total parenteral nutrition. In our study, the combined therapy of pericardial drainage and modified diet with low fat but rich in MCT and high protein brought about complete remission. Prognosis is good if patients receive timely surgical intervention and medical management.

Chylopericardial effusion should be suspected in patients with IgA nephropathy, when signs of tamponade are present. It is critical to exclude underlying causes. Surgical procedures for draining chylous fluid and medical therapy such as a modified diet are effective therapeutic approaches. To date, the challenging issue in chylopericardium is identification of underlying causes. Hopefully, less invasive approaches will be developed in the near future. Additionally, long-term follow up is important to obtain data on the outcome and occurrence of this rare complication of common renal diseases such as IgA nephropathy.

Table 1 Clinical features of chylopericardium in children

\begin{tabular}{|c|c|c|c|c|c|c|c|}
\hline Reference & Age & Gender & Symptoms and signs & Etiology & Treatment & Duration & Prognosis \\
\hline Suri et al. [16] & $4 Y$ & Female & $\begin{array}{l}\text { Orthopnea, anasarca, } \\
\text { tachycardia, tachypnea, } \\
\text { pulsusparadoxus, } \\
\text { engorged neck vein, } \\
\text { muffled heart sound }\end{array}$ & $\begin{array}{l}\text { Superior vena cava } \\
\text { thrombosis }\end{array}$ & $\begin{array}{l}\text { Heparin infusion and oral } \\
\text { warfarin; Modified diet with } \\
\text { low fat but rich in MCT; } \\
\text { Pericardial drainage. }\end{array}$ & 15 days & No recurrence \\
\hline Lope-castilla et al. [17] & $2 M$ & Male & Dyspnea and anorexia & Idiopathic & $\begin{array}{l}\text { Pericardiocentesis; Pericardial } \\
\text { drainage and low-fat total } \\
\text { parenteral nutrition enriched } \\
\text { with MCT }\end{array}$ & 36 days & No recurrence \\
\hline Tan et al. [18] & $5 Y$ & Male & $\begin{array}{l}\text { Cough and dyspnea, } \\
\text { distant heart sounds. }\end{array}$ & Idiopathic & $\begin{array}{l}\text { Ligation of the thoracic } \\
\text { duct and the creation of a } \\
\text { pericardial window }\end{array}$ & 1 week & N/A \\
\hline Rivera-Beltran et al. [15] & $16 Y$ & Male & $\begin{array}{l}\text { Intermittent chest pain } \\
\text { and dizziness }\end{array}$ & Idiopathic & $\begin{array}{l}\text { Pericardiocentesis; MCT-rich } \\
\text { diet; Octreotide; transabdominal } \\
\text { ligation of the thoracic duct with } \\
\text { pericardial-peritoneal shunting }\end{array}$ & $\begin{array}{l}\text { Rapid } \\
\text { recovery }\end{array}$ & No recurrence \\
\hline Musemeche et al. [19] & $12 Y$ & Male & $\begin{array}{l}\text { Orthopnea, distant } \\
\text { heart tones }\end{array}$ & Lymphangiectasia & $\begin{array}{l}\text { Total parenteral nutrition; } \\
\text { Right thoracotomy with } \\
\text { ligation of the thoracic duct }\end{array}$ & $\begin{array}{l}\text { Rapid } \\
\text { recovery }\end{array}$ & No recurrence \\
\hline Attias et al. [20] & $13 Y$ & N/A & Chest pain and fatigue & Idiopathic & $\begin{array}{l}\text { Ligation of thoracic duct } \\
\text { and partial pericardectomy; } \\
\text { MCT-rich diet }\end{array}$ & Rapid recovery & No recurrence \\
\hline
\end{tabular}




\section{Acknowledgements}

We sincerely thank Dr. Fiona Mackie from Sydney Children's Hospital for English editing. We appreciate Dr. Li Shen from the department of cardiothoracic surgery and Dr. Jie Shen from the department of cardiology for their expertise assistant in patient's care. We also express gratitude to Dr. Weiwei Xia and Dr. Zhen Zhu from the department of radiology, Shanghai Children' Hospital for their help in interpreting CT images.

\section{Funding}

This study was financially supported by Shanghai medical excellent youth training program (2017YQ073)

\section{Availability of data and materials}

The datasets supporting the conclusions of this article are included within the article.

\section{Authors' contributions}

YK was responsible for the design of the study, analyzing data and manuscript writing. YC cared for the patient and participated in the design of this study. YW participated in designing the study and analyzing data. SH cared for the patient and participating in manuscript writing. XK participated in the collecting and analyzing data. YZ participated in caring for the patient and manuscript writing. WH participated in the design of the study and revised the manuscript. GZ was responsible for the design of the study, analyzing data and revised the manuscript. All authors read and approved the final manuscript.

\section{Ethics approval and consent to participate}

All examinations and investigations in this case were approved by the Ethical Committee of Shanghai Children's Hospital (China) and were conducted in accordance with the Declaration of Helsinki.

\section{Consent for publication}

Written informed consent was obtained from the parents for publication of this case report and accompanying images. A copy of the written consent is available for review by the Editor of BMC Pediatrics.

\section{Competing interests}

The authors declare that they have no competing interests.

\section{Publisher's Note}

Springer Nature remains neutral with regard to jurisdictional claims in published maps and institutional affiliations.

\section{Author details}

'Department of Nephrology and Rheumatology, Shanghai Children's Hospital, Shanghai Jiao Tong University, Shanghai, China. ${ }^{2}$ Pediatric Intensive Care Unit, Shanghai Children's Hospital, Shanghai Jiao Tong University, Shanghai, China.

Received: 20 April 2016 Accepted: 27 March 2018

Published online: 05 April 2018

\section{References}

1. Sagrista-Sauleda J, Merce AS, Soler-Soler J. Diagnosis and management of pericardial effusion. World J Cardiol. 2011;3(5):135-43.

2. Shakti D, Hehn R, Gauvreau K, Sundel RP, Newburger JW. Idiopathic pericarditis and pericardial effusion in children: contemporary epidemiology and management. J Am Heart Assoc. 2014;3(6):e001483.

3. Nugue O, Millaire A, Porte H, de Groote P, Guimier P, Wurtz A, Ducloux G. Pericardioscopy in the etiologic diagnosis of pericardial effusion in 141 consecutive patients. Circ. 1996;94(7):1635-41.

4. Figueras J, Juncal A, Carballo J, Cortadellas J, Soler JS. Nature and progression of pericardial effusion in patients with a first myocardial infarction: relationship to age and free wall rupture. Am Heart J. 2002; 144(2):251-8.

5. Posner MR, Cohen Gl, Skarin AT. Pericardial disease in patients with cancer The differentiation of malignant from idiopathic and radiation-induced pericarditis. Am J Med. 1981;71(3):407-13.

6. Mandarry MT, Ru XH, Wei ZQ, Ge MJ. Primary idiopathic chylopericardium: rare case with a synopsis of the literature. Singap Med J. 2012;53(7):e156-8.
7. Lee SM, Rao VM, Franklin WA, Schiffer MS, Aronson AJ, Spargo BH, Katz Al. IgA nephropathy: morphologic predictors of progressive renal disease. Hum Pathol. 1982;13(4):314-22.

8. Silva MA, Martins AS, Campos NL, Andrade RR, Tohi LM, Hueb JC. Primary idiopathic chylopericardium-case report. Arq Bras Cardiol. 2009; 92(6):e40-3. e67-70

9. Mehrotra S, Peeran NA, Bandyopadhyay A. Idiopathic chylopericardium: an unusual cause of cardiac tamponade. Tex Heart Inst J. 2006;33(2):249-52.

10. Gallant TE, Hunziker RJ, Gibson TC. Primary chylopericardium: the role of lymphangiography. AJR Am J Roentgenol. 1977;129(6):1043-5.

11. Nanjo S, Yamazaki J, Tsubuku M, Ohyama T, Ohtsuka T, Nakano H. Primary idiopathic chylopericardium: report of two cases. Ann Nucl Med. 2004;18(6):537-9.

12. Groves LK, Effler DB. Primary chylopericardium. N Engl J Med. 1954;250(12): $520-3$

13. Mikroulis D, Didilis V, Bitzikas G, Bougioukas G. Octreotide in the treatment of chylothorax. Chest. 2002;121(6):2079-80. author reply 2080-2071

14. Han Z, Li S, Jing H, Liu H. Primary idiopathic chylopericardium: a retrospective case series. BMC Surg. 2015;15:61.

15. Rivera-Beltran S, Ortiz VN, Diaz R, Hernandez JA. Transabdominal ligation of the thoracic duct with pericardial-peritoneal shunting in a case of primary idiopathic chylous pericardial effusion. J Pediatr Surg. 2013:48(6):1434-7.

16. Suri D, Gupta N, Morigeri C, Saxena A, Manoj R. Chylopericardial tamponade secondary to superior vena cava thrombosis in a child with nephrotic syndrome. Pediatr Nephrol. 2009;24(6):1243-5.

17. Lopez-Castilla JD, Soult JA, Falcon JM, Munoz M, Santos J, Gavilan JL, Rodriguez A. Primary idiopathic chylopericardium in a 2 month old successfully treated without surgery. J Pediatr Surg. 2000;35(4):646-8.

18. Tan JX, Fu Y, Chen J. Primary idiopathic chylopericardium: a case report. Cardiol Young. 2013;23(5):773-5.

19. Musemeche CA, Riveron FA, Backer CL, Zales VR, Idriss FS. Massive primary chylopericardium: a case report. J Pediatr Surg. 1990;25(8):840-2.

20. Attias D, Ou P, Souillard P, Boudjemline $Y$, Sidi D, Bonnet D. Spontaneous idiopathic chylopericardium in childhood. Arch Mal Coeur Vaiss. 2006:99(5):529-31.

\section{Submit your next manuscript to BioMed Central and we will help you at every step:}

- We accept pre-submission inquiries

- Our selector tool helps you to find the most relevant journal

- We provide round the clock customer support

- Convenient online submission

- Thorough peer review

- Inclusion in PubMed and all major indexing services

- Maximum visibility for your research

Submit your manuscript at www.biomedcentral.com/submit
Biomed Central 